\title{
Population Structure and Regeneration Status of Most Abundant Medicinal Woody Plants in Mabira Central Forest Reserve Management Zones
}

\author{
Charles Lwanga Tumuhe*, Rogers Niwamanya Mwine, Sandra Manana \\ Makerere University, Department of Environmental Management, 7062, 256 Kampala, Uganda
}

Received: 22 October 2017

Accepted: 30 January 2018

Published online: 31 October 2018

\begin{abstract}
In the rural areas $90 \%$ of the Ugandans use plants for their medicinal uses. Communities around Mabira Central Forest Reserve (CFR) harvest plants for medicinal purposes. The increased uptake of herbal medicine is a threat to the abundance and health of medicinal trees. This research determined the species population structure and regeneration status of most abundant woody medicinal plant species in Mabira CFR. Sixty nested plots measuring $20 \times 10 \mathrm{~m}$ were established adjacent to transects, 20 plots per management zone. The species sampled were identified, counted, and their diameter at breast height (dbh) taken. Their density was computed. Using the dbh classes and density data, dbh distributions were established. Using Kruskal- Wallis test we ascertained if significant differences existed in medicinal plant species densities for size classes in the 3 zones. Using linear regression we got relationship between plant density and dbh. A regression analysis of In $(\mathrm{Ni}+\mathrm{l})$ against $d i$ was made to cater for the zero values of abundance per hectare. The population had a steep negative slope, meaning that it is stable and naturally replacing itself. There was a general decline in species density with $\mathrm{dbh}$. The $<5 \mathrm{dbh}$ size class had the biggest number of individuals per hectare in the production zone. The production zone had a high regeneration potential due to most individuals being in the smallest size class. Density had a negative linear relationship with dbh. There was a significant relationship between dbh and density of species. The tree species sampled were generally naturally regenerating.
\end{abstract}

Keywords: dbh, population structure, central forest reserve, medicinal plants

\section{Introduction}

Uptake and utilization of medicinal plants is on the raise globally according to Asiimwe et al, (2014), Joshi A R. and Joshi $K$, (2000), Kamatenesi-Mugisha and Oryem-Origa $H$, (2005), and WHO, (2013). Over $80 \%$ of the population of people in the developing countries depends on medicinal plants for their healthcare needs (WHO, 2013). In the rural areas 90\% of the people in Uganda almost entirely use plants for their medicinal uses according to Kamatenesi and Oryem (2007) and Kakudidi, (2000), Uganda has up-scaled the use of herbal medicine (WHO, 2013 and Uganda Gazette No.7) and is having ${ }^{*}$ Corresponding author: Charles Lwanga Tumuhe
e-mail: tumchaz34@gmail.com 
Charles Lwanga Tumuhe et al.

plans of integrating herbal medicines into the main health care systems. The most commonly used plant species by communities around Mabira for medicinal purposes in Mabira central forest reserve include; Warbugia ugandensis, Prunus Africana, Piptadeniastrum africana, Eryrina abyssinica and Albizia coriaria. Their Medicinal values are: Prunus africana is used to treat Gonorrhea, and Kidney diseases, Albizia coriaria is used to treat Epilepsy, Menorrhagia, venereal diseases, Wabughia ugandensis treats Erectile dysfunctions, venereal diseases ,ulcers, TB, constipation, skin to mention but a few. Piptadeniastrum africana treats male impotence, Hemorrhoid, dysmenorrhea, Eryrina abyssinica is a remedy to snake bites, syphilis, gonorrhea, ulcers and emetic disease. However the increased uptake of herbal medicine is a threat to the abundance and health of medicinal woody and non-woody plant tree species. The unsustainable exploitation results in the loss of herbal medicine sources. This is a threat to the abundance and health of medicinal woody and non-woody plant tree species. The mostly used medicinal plants in Mabira according to Tabuti et al (2007) are Alstonia boonei, Mondia whitei, Spathodea campanulata, Albizia corriaria, Erythrina abyssinica, Piptadeniastrum Africana, Prunus africana, Mormodica feotida, Vernonia amygdalina among others. The unsustainable exploitation results in the loss of herbal medicine sources. There is however dearth of information on population structure and regeneration status of medicinal tree plants in Mabira central Forest Reserve in Uganda. Such information is important for designing its conservation programs of the woody medicinal tree species in the CFR. In this research study, we explore on the species population structure of most abundant woody medicinal plants and regeneration status of most abundant woody medicinal plant species in Mabira CFR.

\section{Study area, methods and materials}

\section{Description of study area}

Mabira CFR is found in southern Uganda, on the crescent of Lake Victoria. It is situated between latitude $0^{\circ} 22^{\prime}$ and $0^{\circ} 35^{\prime} \mathrm{N}$ and between longitude $32^{\circ} 56^{\prime}$ and $33^{\circ} 02^{\prime} \mathrm{E}$. Its altitudinal range $1070 \mathrm{~m}-1340 \mathrm{~m}$. It occupies an area of $306 \mathrm{Km}^{2}$. It is as a medium-altitude, moist semi-deciduous forest. The rainfall is bimodal, with most of the mean annual rainfall of $1640 \mathrm{~mm}$. The soils are deep red clays, classified as Ferrisols.

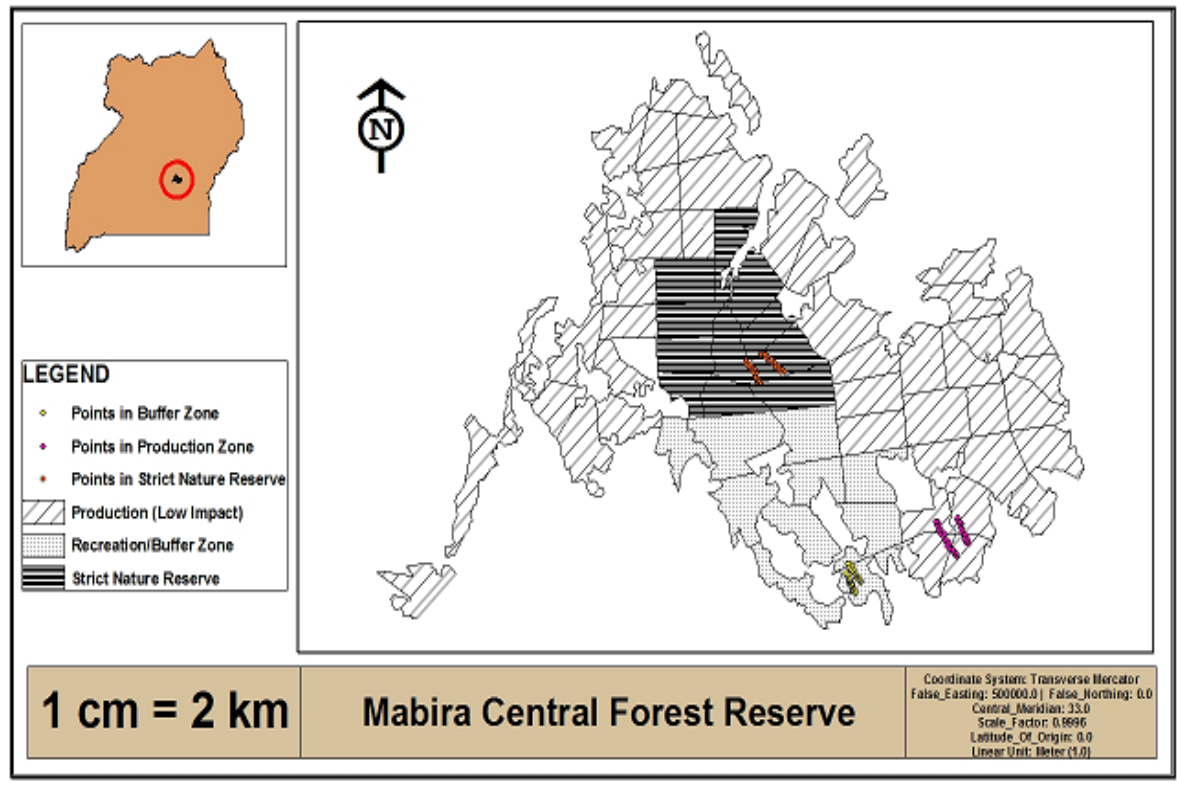

Fig. 1 Map of study area. 


\section{Methods}

The study was carried out in 3 management zones (Strict Nature Reserve, Buffer, and production zones). Field surveys were conducted in the forest reserve in July 2017 in the 3 management zones of Mabira CFR. Sixty - $20 \times 10 \mathrm{~m}$ plots were established adjacent to established transects ( 20 plots per management zone). Two transects were established per zone and ten plots laid in them. Each study plot of $20 \mathrm{~m} \times 10 \mathrm{~m}$ was nested as done by Eilu and Obua (2005) and Okiror et al., (2012). Within the largest plot of $20 \times 10 \mathrm{~m}$, large medicinal plant species $(\geq 10 \mathrm{~cm} \mathrm{dbh})$ were enumerated. In $10 \times 10 \mathrm{~m}$ subplot, medicinal tree plant species of size class $(5 \mathrm{~cm}<10 \mathrm{~cm} \mathrm{dbh})$ were assessed and in a $5 \times 5 \mathrm{~m}$ subplot the size class $(<5 \mathrm{~cm} \mathrm{dbh})$ recorded. The species sampled were identified, counted, and their dbh taken with Vanier caliper and measuring tape and recorded on data sheets. Diameter was measured at breast height (dbh, $1.3 \mathrm{~m}$ high). All trees found in the plots were enumerated and identified using vegetative field characteristics and scientific identification keys of Hamilton 1981 (Obua and Eilu, 2005 ) and with the help of experienced botanists from National Forestry Authority. The first plot of 20 $\times 10 \mathrm{~m}$ plot was randomly selected adjacent to established transect and set at a distance of $10 \mathrm{~m}$ away from transect to avoid edge effect. Using GPS equipment and Compass, S-E direction was taken and systematically locating subsequent plots. Records from 10 plots were taken in S-E direction before switching to second transect separated by $300 \mathrm{~m}$. Plots were $50 \mathrm{~m}$ apart. A total of 60 plots were established, 20 plots per zone. The tree population structure was studied according to Misra R. (1968), Mueller-Dombois D., Ellenberg H (1974). The data collected were also used to compute frequencies, densities and draw density distributions according to Lalfakawma et al. (2009).

\section{Data processing and analysis}

Data recorded on data sheets was entered in spreadsheet MS excel program of Windows. We then computed the species abundance for all the medicinal plants we recorded on data sheets using pivot table in MS excel. We also determined the frequency (number of plots having each of the medicinal plant species). The total area sampled in each zone was calculated by multiplying the plot size by the total number of plots surveyed. Abundance (number of individuals trees) was recorded for each species in each plot, transect and management zone. The Strict Nature Reserve had 36, Buffer, 35 and Production 32 species. Selection of most abundant woody tree medicinal species was made basing on their densities and then size class distribution (SCD) analysis was done. Four dbh size classes were used (i.e. below 5, 5-10, 10-30 and 30-60) for establishment of density distributions. The density of each species (number of individuals counted per area sampled) was computed by dividing the total number of individuals by total area sampled. Using the dbh classes and density data, dbh distributions were established for all zones. Using Kruskal- Wallis test we ascertained if significant differences existed in medicinal plant species densities for size classes in the 3 zones. Eight size classes (degree of freedom, $d f=7$ ) were here adopted to increase number of observations (n) and minimize error. The size classes used during this test were; $<5,5-10,10-20,20-30,30-40,40-50,50-60,>60$ for the three management zones. The total $d f$ was 23 . Using linear regression we got relationship between plant density and dbh to find out if number of individuals per unit area changes with size (dbh). We ran regression analyses between density (plants ha ${ }^{-1}$ ) and dbh for most abundant species in each zone. A regression analysis was run using SPSS program for windows to establish linear relationship between size (dbh) of species and their density. Scatter plots of density against dbh were established. A regression plot of $\operatorname{In}(\mathrm{Ni}+\mathrm{l})$ against $d i$ was made to cater for the zero values of abundance per hectare. Where $(\mathrm{Ni}+\mathrm{l})$ is abundance per ha and $d i$ is mid- point of size class as used by Lykke (1998), Condit et al., Eilu and Obua (2005), Tabuti (2007), Mwavu and Witkowski (2009). To calculate the regression slope, the size-class midpoint 
Charles Lwanga Tumuhe et al.

(di) was treated as the independent variable and the number of individuals per unit area (density) in each size class as the dependent variable (See Lykke, 1998; Obiri et al., 2002).

\section{Results and discussion}

The most abundant species in the production zone were Cola gigantica A chev. and Coffea longi folia Ruiz; in the buffer zone were Teclea nobilis and Elastica Preus Stapf.;strict nature reserve were Acalypha neptunica Mull. Arg and Margaritaria discoidea

\section{Density distribution per zone for the four size classes}

A plot of density against only size classes per zone showed a distribution as below.

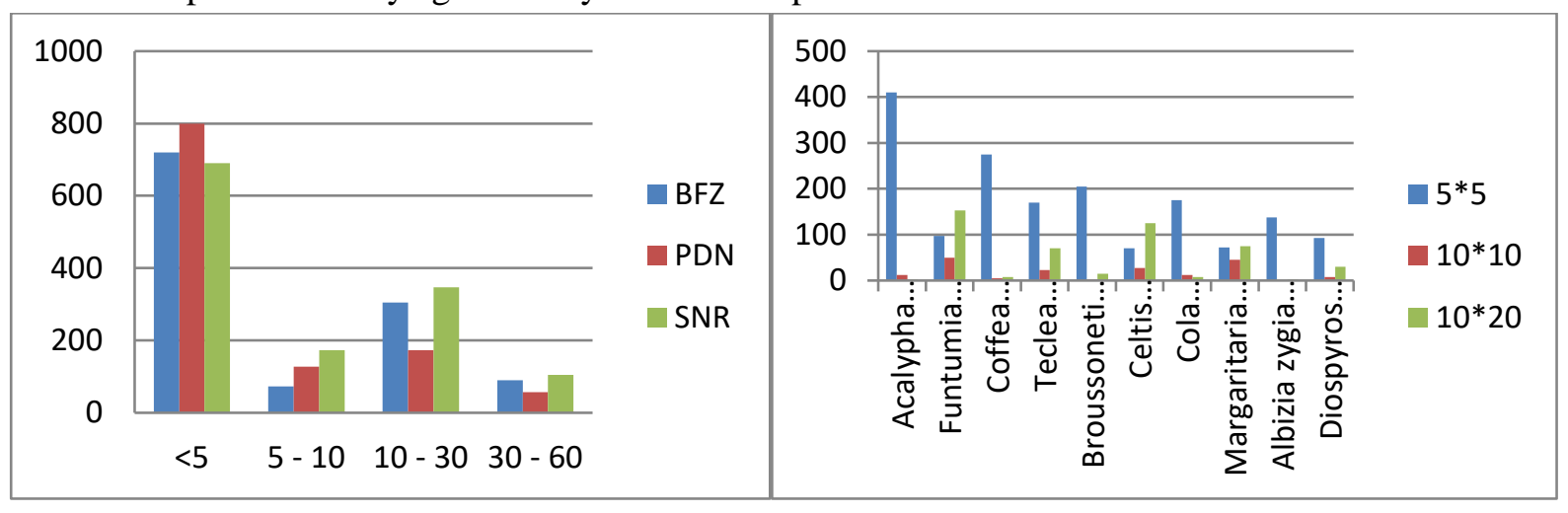

Fig. 4 Density distribution per zone.

Fig. 5 Density distribution for most abundant species. (Key: $\mathrm{BFZ}=$ Buffer zone, $\mathrm{PDN}=$ production zone $\mathrm{SNR}=$ strict nature reserve)

Tab. 1 Regression functions for density and dbh for the three management zones.

\begin{tabular}{lclc}
\hline & Production & \multicolumn{1}{c}{ Buffer } & \multicolumn{1}{c}{ SNR } \\
\hline $\begin{array}{l}\text { Regression } \\
\text { function }\end{array}$ & Density $=5.93-0.0662 \mathrm{dbh}$ & $\begin{array}{l}\text { Density }=5.73- \\
0.05 \mathrm{dbh}\end{array}$ & $\begin{array}{l}\text { Density }=6.098- \\
0.055 \mathrm{dbh}\end{array}$ \\
\multicolumn{1}{c}{$\mathbf{R}^{\mathbf{2}}$} & 0.861491392 & 0.758855 & 0.912035 \\
\hline
\end{tabular}

\section{Population structure}

A size class frequency distribution plot was drawn by plotting the plant density, against the four size classes (Fig 4). A linear regression function was also calculated for the SCD using the software SPSS for windows (table 1). The population had a steep negative slope, meaning that it is stable and naturally replacing itself.

To calculate the regression slope, the size-class midpoint (di) was treated as the independent variable and the number of individuals per unit area (density) in each size class as the dependent variable. There was a general decline in species density with size (dbh) (Fig 5). The $<5$ dbh size class has the biggest number of individuals per hectare in the production zone.

The production zone had a high regeneration potential due to having most individuals in the smallest size class. No species has individuals in all size classes. The $<5$ and $50-60$ size classes had the highest $(69.1 \%)$ and lowest $(2.1 \%)$ abundances per ha respectively. Cola gigantea A chev, Funtumia elastica (P.Preuss) Stapf and Markhamia lutea K.Schum were the most frequent species in the production. Ficus mucuso Welwex ex Ficalho, Macaranga tenarious and Tabana montana holstii were the least frequent species. 
Density had a negative linear relationship with dbh (Fig 5). This confirms that density of species declines with size (dbh) as already noted above. There was a significant relationship between dbh and density of species $(p=0.03)$ according to the Kruskal - Wallis test performed with SPSS for Windows. There was no significant difference in densities of the respective dbh classes in the three management zones $(p=0.778)$. The SNR had the highest dbh median $(81.25 \mathrm{~cm})$ and the production zone had lowest dbh median $(38.75 \mathrm{~cm})$

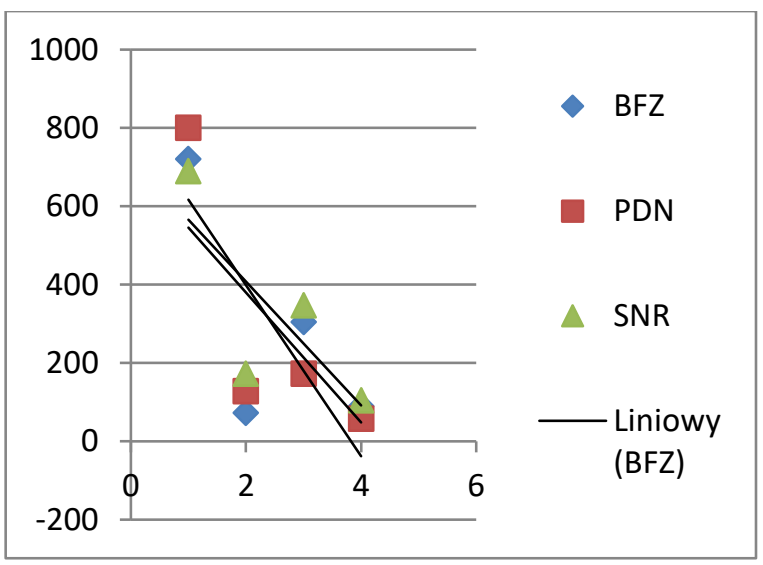

Fig. 5 dbh-density linear relation for all zones.

\section{Regeneration status}

The tree species sampled were naturally regenerating. Most (60.49\%) of species studied had their individuals less than $5 \mathrm{~cm}$ compared to the $28.02 \%$ with size greater than $10 \mathrm{~cm}$ in dbh. The least proportion $(11.48 \%)$ in the intermediate dbh class showed that the survival rate of the produced seedlings was low. Antiaris toxicaria Lesh, Celtis durandii, Ficus sycomorus L, Sapium Ellipticum (C. Krauss) Pax had most of their individuals in the mature (big) size class and almost none of their population was regenerating (in seedlings form).

\section{Discussions}

There was highest density of seedlings. Such high abundances cannot be seen in subsequent and mature size classes implying their loss from the population. This loss weakens the population. The absence of adults in a population affects recruitment into the population by seeds. A straight line relationship between density $(\ln (\mathrm{Ni}+1)$ and dbh midpoints $(d i)$ showed negative exponential curves in all the three management zones. This is in conformity with the findings of Sahoo, U K. (2008). However, the lower density of lower diameter class (5-10 cm dbh) as compared to intermediate girth class (10-30 dbh) gave the appearance of a positively skewed distribution curve for all management zones. This could have been due to selective felling of lower as well as higher girth class tree or due to low tree mortality and lower removal rate across the intermediate diameter classes and lower recruitment of component tree species. The lower density of the higher dbh classes of trees can be attributed to the relatively high mortality of large canopy trees. The above characteristics of girth classes also suggests that the forest's woody medicinal plants are still growing and yet to reach to their climax stage. The existence of lowest densities in the highest dbh classes can be attributed to disturbances by the neighboring communities for medicine and timber. The population had a steep negative slope, meaning that it is stable and naturally replacing itself. This confirms the results of Hall \& Bawa, (1993), Lykke, (1998), and Obiri et al., (2002).It can therefore be suggested that suitable management strategies 
Charles Lwanga Tumuhe et al.

have to be taken up for careful utilization of woody medicinal trees species in the forest for example selective harvesting of these trees to enhance sustainable forest production.

\section{Conclusion and recommendations}

The number of individuals for most species decreased with size. The bigger the trees became they fewer they got. Both the young and old species need to be protected from disturbance factors. The seeds and seedlings produced by mature ones generally were more than their abundance. Most species were only abundant and frequent in specific zones. Conservation efforts have to be distributed almost equally to all management zones. None of the species with exception of Funtumia elastica are only highly abundant in at least one management zone. All individuals except a few (Antiaris toxicaria Lesh, Celtis durandii, Ficus sycomorus L, Sapium Ellipticum (C. Krauss) Pax) are represented in the young and mature groups and thus have good regenerative capacity. Socio - economic surveys need to be carried out to establish the utilization of these medicinal woody species by communities in the communities around Mabira Central Forest Reserve to enhance on their protection.

\section{References}

Asiimwe S, Namutebi A, Borg-Karlsson A, Kamatenesi-Mugisha M, Oryem-Origa H (2014) Documentation and Consensus of Indigenous knowledge on medicinal plants used by the local communities in Western Uganda. J Nat Prod Pl Res; 4(1):34-42.

Joshi AR, Joshi K (2000) Indigenous knowledge and uses of medicinal plants by local communities of the Kali Gandaki Watershed Area, Nepal. J Ethnopharmacol.;73:119-29

Kamatenesi MK, Acipa A, Oryem-Origa H (2011) Medicinal plants of Otwal and Ngai sub counties in Oyam District, Northern Uganda ;7.

Kamatenesi-Mugisha M, Oryem-Origa H (2005) Traditional herbal remedies used in the management of sexual impotence and erectile dysfunction in Western Uganda. Afr Health Sci.; 5(1):40-9.

Lalfakawma UK, Sahoo S, Roy K, Vanlalhriatpuia PC, Vanalalhluna (2009) Community composition and tree population structure in undisturbed and disturbed tropical semi evergreen forest stands of north-east India, Aizawl: 796 009, India.

Lykke AM (1998) Assessment of species composition change in savanna vegetation by means of woody plants' size class distributions and local information. University of Aarhus, Nordlandsvej 68, DK8240 Risskov, Denmark.

Misra R (1968) Ecology work book. - Oxford and IBH, Calcutta.

Sahoo UK, Tomar JMS, Upadhyaya K (2008) Phytosociological analysis of Pinus kesiya stands exposed to varying intensities of disturbance at Umiam Watershed in Northeast India. - International Journal of Ecology and Environmental Sciences 34(4):337-346.

Tabuti JRS, Mugula BB (2007) The ethno-botany and ecological status of Albizia coriaria Welw. ex Oliv. in Budondo Sub-county, eastern Uganda, Kampala, Uganda.

Uganda Gazzette (2015) Indigenous and Complementary Medicine Bill 2015, Vol. VIII: Bill No. 7.

WHO (2002) Mental Health Global Action program (mHLGAP). Geneva, Switzeland: World Health Organization.

WHO (2013) World Health Organisation strategy on traditional Medicine 2014-2023, Geneva, Switzeland: World Health Organisation. 